\title{
Flora do Espírito Santo: Ingeae (Leguminosae): parte 1
}

\author{
Flora of Espírito Santo: Ingeae (Leguminosae): part 1
}

Aline Pitol Chagas ${ }^{1,2}$, Valquíria Ferreira Dutra ${ }^{2}$ \& Flávia Cristina Pinto Garcia ${ }^{3,4}$

\begin{abstract}
Resumo
Ingeae é uma importante tribo da família Leguminosae com cerca de 950 espécies em 36 gêneros, dos quais 24 são endêmicos do Novo Mundo. Este trabalho apresenta o estudo florístico de 16 espécies de Ingeae, reunidas em sete gêneros: Abarema (seis spp.), Albizia (duas spp.), Calliandra (duas spp.), Chloroleucon (duas spp.), Enterolobium (duas spp.), Leucochloron (uma sp.) e Zygia (uma sp.) ocorrentes no Espírito Santo. O gênero Inga, devido ao grande número de espécies, será publicado posteriormente. Dentre as espécies estudadas, 14 (88\%) são endêmicas do Brasil, sendo uma, Abarema barnebyana, restrita ao Espírito Santo e sete (44\%) restritas ao bioma Floresta Atlântica. No estado, 14 espécies ocorrem em Floresta Ombrófila Densa. Na Restinga, são encontradas oito espécies e na Floresta Estacional Semidecidual, sete espécies. São apresentadas chaves para identificação, descrições, ilustrações, comentários taxonômicos, períodos de floração e frutificação, distribuição geográfica e habitats preferenciais.
\end{abstract}

Palavras-chave: clado Mimosoide, Fabaceae, Floresta Atlântica.

\begin{abstract}
Ingeae is an important tribe of Leguminosae with 950 species in 36 genera, 24 endemic to the New World. This manuscript is the florist treatment of 16 species of Ingeae, organized in seven genera: Abarema (six spp.), Albizia (two spp.), Calliandra (two spp.), Chloroleucon (two spp.), Enterolobium (two spp.), Leucochloron (one sp.) e Zygia (one sp.) in the state of Espírito Santo. The genus Inga will be discussed in a forthcoming manuscript, due to its number of species. Among the recorded species, fourteen (88\%) are endemic to Brazil and Abarema barnebyana is restricted to Espírito Santo. Seven species (44\%) are restricted to the Atlantic Forest biome. Fourteen species occurs in the Dense Rain Forest, eight species are found in the Restinga, and seven species in the Seasonal Semidecidual Forest. Identifications keys, descriptions, illustrations, taxonomic comments, flowering and fruiting periods, geographic distribution, and habitats are provided.
\end{abstract}

Key words: Mimosoid clade, Fabaceae, Atlantic Forest.

\section{Introdução}

Leguminosae Adans. é a terceira maior família da flora do Espírito Santo em número de espécies com 384 espécies e 114 gêneros (Dutra et al. 2015). Também é a família mais diversa da Flora do Brasil, com 2.834 espécies e 222 gêneros, e a segunda mais numerosa na Floresta Atlântica, com 996 espécies (Forzza et al. 2010; BFG 2015). É considerada a terceira maior família de angiospermas com 770 gêneros, 19.500 espécies e
36 tribos com distribuição cosmopolita, ocorrendo especialmente nas florestas tropicais e subtropicais (Lewis et al. 2005; LPWG 2017). Em importância econômica, as Leguminosae são consideradas por Wojciechowski et al. (2004) a segunda maior família, perdendo apenas para Poaceae.

Leguminosae compreende seis subfamílias monofiléticas: Caesalpinioideae DC., Cercidoideae LPWG, Detarioideae Burmeist., Dialioideae LPWG, Duparquetioideae LPWG e

\footnotetext{
${ }^{1}$ Universidade Federal de Viçosa, Pós-graduação em Botânica, Depto. Biologia Vegetal, 36570-000, Viçosa, MG, Brasil.

${ }^{2}$ Universidade Federal do Espírito Santo, Herbário VIES, Depto. Ciências Biológicas, Av. Fernando Ferrari 514, 29075-910, Vitória, ES, Brasil.

${ }^{3}$ Universidade Federal de Viçosa, Depto. Biologia Vegetal, Av. P.H. Rolfs s/n, Campus da UFV, 36570-000, Viçosa, MG, Brasil.

${ }^{4}$ Autor para correspondência: fcgarcia@ufv.br
} 
Papilionoideae DC., com a tradicional subfamília Mimosoideae formando o clado Mimosoide dentro de Caesalpinioideae (LPWG 2017). Apesar das mudanças taxonômicas recentes nas subfamílias, os gêneros deste clado permanecem reunidos nas tribos não monofiléticas: Acacieae Dumort., Ingeae Benth., Mimoseae Bronn e Mimozygantheae Burkart (Lewis et al. 2005; Brown 2008).

A tribo Ingeae, originalmente descrita por Bentham (1865), é caracterizada por apresentar estames numerosos e unidos na base, formando um tubo. Posteriormente, vários táxons foram incluídos e excluídos da tribo. Nielsen (1981), por exemplo, considerou 21 gêneros e Polhill (1994) reconheceu 25 gêneros em Ingeae. Barneby e Grimes (1996) ampliaram a tribo para 34 gêneros e, mais recentemente, Lewis \& Rico Arce (2005) reconheceram 36 gêneros e 951 espécies, com base em dados moleculares e morfológicos.

As espécies de Ingeae são caracterizadas pelo hábito arbóreo e arbustivo, raramente escandente; folhas bipinadas, exceto em Inga e em algumas espécies de Zygia, que apresentam folhas pinadas; estípulas inconspícuas; frequentemente apresentam nectários extraflorais; inflorescências capituliformes, corimbosas, umbeliformes, racemosas, espiciformes ou paniculadas, reunidas em fascículos, panículas ou isoladas, axilares, terminais ou caulifloras; flores homomórficas ou heteromórficas; cálice gamossépalo valvar e corola gamopétala valvar; estames numerosos, monadelfos; ovário unicarpelar, gineceu uni ou pluricarpelar, ovário unicarpelar; frutos geralmente legume ou folículo; sementes geralmente com pleurograma (Wu \& Nielsen 2010). Análises filogenéticas baseadas em dados moleculares e morfológicos indicam que Ingeae é parafilética com Acacieae, uma vez que alguns membros de Acacia, subgênero Phyllodineae, também apresentam estames unidos em tubo (Barneby \& Grimes 1996; Lewis et al. 2005; Brown et al. 2008).

O objetivo deste estudo foi contribuir com o conhecimento da diversidade de Ingeae no Espírito Santo, exceto Inga que, devido ao grande número de espécies, será apresentado em outro trabalho. São apresentadas chaves de identificação, descrições para o reconhecimento dos taxa, ilustrações, comentários taxonômicos, além de dados de floração e frutificação, distribuição geográfica e hábitats preferenciais para os gêneros Abarema, Albizia, Calliandra, Chloroleucon, Enterolobium, Leucochloron e Zygia.

\section{Material e Métodos}

$\mathrm{O}$ estudo taxonômico foi realizado entre os anos de 2012 e 2014 com base na análise morfológica de espécimes coletados no Espírito Santo e depositados no acervo dos herbários HUEFS, MBML, R, RB, VALE, VIC e VIES (acrônimos de acordo com Thiers, continuamente atualizado), além de expedições de campo complementares realizadas em Unidades de Conservação do Estado. Os materiais coletados foram herborizados de acordo com Fidalgo \& Bononi (1989) e, após a identificação, depositados no acervo do herbário VIES, sendo as duplicatas enviadas para os herbários VIC, MBML e RB. A identificação dos materiais examinados foi realizada com base na análise morfológica, em consulta à literatura taxonômica especializada, além de comparação com exemplares de herbário e imagens digitais dos tipos e de exsicatas identificadas por especialistas disponíveis no Herbário Virtual Reflora (<http://www. herbariovirtualreflora.jbrj.gov.br $>$ ).

A análise morfológica do material botânico incluiu as medidas das partes vegetativas em material desidratado, enquanto que as partes florais foram medidas após a reidratação ou através do material estocado em etanol, sendo apresentadas nas descrições as variações qualitativas e quantitativas para espécies e gêneros. As medidas foram obtidas com paquímetro digital (precisão de $0,01 \mathrm{~mm}$ ) e tomadas nas regiões de maior comprimento e/ou largura das estruturas adultas; foram consideradas subsésseis as estruturas que apresentaram eixo de sustentação de até $1 \mathrm{~mm}$ de comprimento. A terminologia empregada nas descrições morfológicas dos gêneros e espécies foi baseada em Radford et al. (1974), exceto nectários e frutos e sementes, que foram baseados em Fernandes (2011) e Barroso et al. (1999), respectivamente. Para as inflorescências do gênero Abarema, foi utilizada a terminologia de Iganci (2008).

As ilustrações foram realizadas com o auxílio de uma câmara clara acoplada a estereomicroscópio a partir de amostras botânicas herborizadas. Os nomes populares foram obtidos das etiquetas dos exemplares examinados. Para o material examinado, foi selecionado um material testemunho por município de ocorrência no Espírito Santo, os demais exemplares examinados foram citados no material adicional examinado. Os dados de distribuição geográfica e ocorrência 
nas diferentes formações vegetacionais foram obtidos nas etiquetas dos exemplares examinados, das coletas georreferenciadas, da lista de espécies da Flora do Brasil ( $<$ http://floradobrasil.jbrj. gov.br/>) e das obras de revisões dos gêneros. Quando necessário, a ocorrência das espécies nos municípios do Espírito Santo foi extraída da rede de banco de dados Species Link ( $<$ http://www. splink. rg.br/index/ $>$ ) e confirmadas nas etiquetas de exsicatas digitalizadas no Herbário Virtual Reflora (<http://www.herbariovirtualreflora. jbrj.gov.br $>$ ). A identificação das formações vegetacionais ocorrentes no estado seguiu a classificação do Instituto Brasileiro de Geografia e Estatística (IBGE 2012), sendo que, para a Floresta Ombrófila Densa, foi utilizada a divisão sugerida por Thomaz (2010). O período de floração e frutificação foi obtido das etiquetas dos exemplares examinados e observações realizadas em campo.

Para a distribuição geográfica no Espírito Santo foi adotada a divisão geopolítica estadual em mesorregiões do Instituto Brasileiro de Geografia e Estatística (IBGE 2011; IJSN 2011): [1] Central Espírito-santense; [2] Litoral Norte Espírito-santense; [3] Noroeste Espírito-santense; e [4] Sul Espírito-santense (Fig. 1).

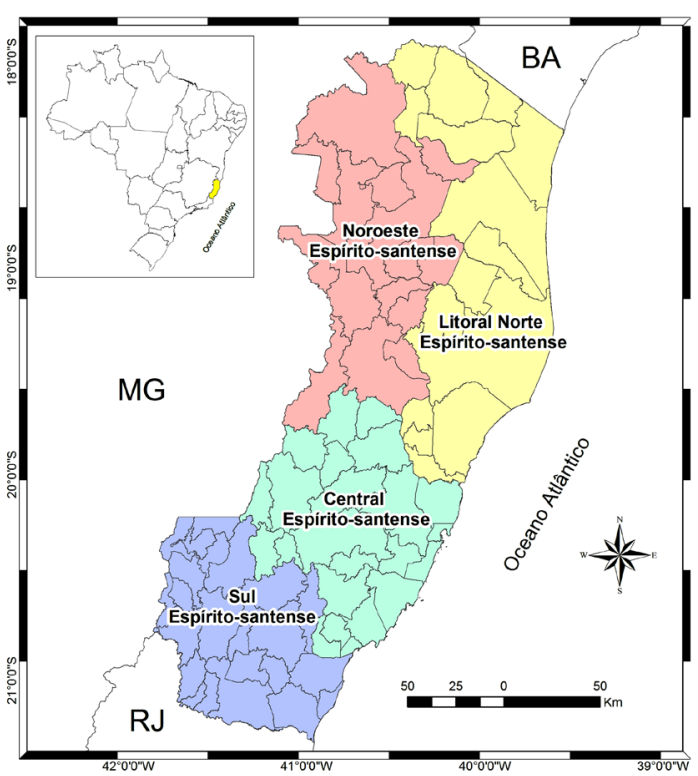

Figura 1 - Mesorregiões geográficas do Espírito Santo. Fonte: IBGE 2011.

Figure 1 - Geographical mesoregions of Espírito Santo. Source: IBGE 2011.

\section{Resultados e Discussão}

Ingeae Benth.

Árvores, arbustos, subarbustos, raramente ervas; ramos inermes, raramente armados, glabros ou indumentados; gemas peroladas presentes ou ausentes; estípulas caducas ou persistentes. Folhas pinadas ou bipinadas, pinas 1-19 pares; nectários presentes no pecíolo e/ou entre pares de pinas e foliólulos, raramente ausentes, sésseis, subsésseis ou estipitados, pateliformes, cupuliformes, ciatiformes, verruciformes ou capitados; foliólulos 1-27 pares. Inflorescências ramifloras, axilares ou apicais, raramente caulifloras, unidades em cacho, capituliformes, espiciformes ou umbeliformes, reunidas em fascículos, panículas ou isoladas; brácteas caducas ou persistentes. Flores homomórficas ou heteromórficas, gamossépalas, gamopétalas; androceu monadelfo, monocolores ou bicolores, tubo incluso ou exserto, estames 10-249; disco nectarífero presente ou ausente; estemonozone presente ou ausente; gineceu 1-2-carpelar. Fruto legume, legume bacóide, legume nucóide ou folículo; sementes planas ou convexas, monocolores ou bicolores, pleurograma presente ou ausente, testa membranácea ou óssea.

No Espírito Santo, Ingeae está representada por oito gêneros e 43 táxons, dos quais Inga é o mais diverso, com 27 táxons, cujo estudo taxonômico será publicado posteriormente. Abarema, Albizia, Calliandra, Chloroleucon, Enterolobium, Leucochloron e Zygia somam 16 espécies. Os gêneros que ocorrem no Estado representam cerca de $50 \%$ dos 16 gêneros distribuídos no Brasil, enquanto que os táxons específicos e infraespecíficos correspondem a $14 \%$ da diversidade brasileira de Ingeae.

A riqueza de espécies de Ingeae no Espírito Santo deve-se, principalmente, a cobertura vegetal atlântica do estado que compõe um dos principais centros de diversidade da tribo, e que revela um conjunto de 18 espécies de Ingeae endêmicas do Bioma. A maioria dos registros de Ingeae no Espírito Santo está nas mesorregiões Central e Litoral Norte, em Mata de Encosta e Mata de Tabuleiro, respectivamente, o que é justificado pelo esforço de coleta intensivo na região serrana de Santa Teresa e Reserva Natural Vale, em Sooretama e Linhares. Os gêneros de Ingeae podem ser reconhecidos, no Espírito Santo, pelas características apresentadas na chave de identificação a seguir. 
Chave de identificação dos gêneros Abarema, Albizia, Calliandra, Chloroleucon, Enterolobium, Leucochloron e Zygia no Espírito Santo

1. Nectários foliares ausentes

3. Calliandra

1'. Nectários foliares presentes.

2. Ramos armados

4. Chloroleucon

2'. Ramos inermes.

3. Legume nucóide ou bacóide, auriculiforme

5. Enterolobium

3'. Legume ou folículo, reto a espiralado.

4. Inflorescências em racemos; estemonozone presente; sementes bicolores...1. Abarema

4'. Inflorescências capituliformes, espiciformes ou umbeliformes; estemonozone ausente; sementes monocolores.

5. Ramos com cicatrizes de braquiblastos; fruto folículo com valvas coriáceas

5'. Ramos sem cicatrizes de braquiblastos; fruto legume ou folículo com valvas cartáceas ou lenhosas.

6. Folhas com 1 par de pina; inflorescências caulifloras

7. Zygia

6'. Folhas com 4-14 pares de pinas; inflorescências ramifloras

2. Albizia

1. Abarema Pittier, Arb. Legum. 56. 1927.

Árvores ou arbustos; ramos inermes; estípulas caducas, gemas peroladas ausentes. Folhas bipinadas, pinas 1-9 pares; nectários foliares sésseis, cupuliformes a verruciformes, no pecíolo e, geralmente, entre pares de pinas e de foliólulos; parafilídeos ausentes; foliólulos assimétricos, elípticos, oblongo-lanceolados, obovados ou rômbicos, venação peninérvea. Unidades de inflorescências em racemos laxos, congestos ou capitados, reunidos em panículas, em fascículos ou isoladas, axilares; brácteas caducas. Flores homomórficas ou heteromórficas, 5-meras; estames 19-55, monocolores, alvos, tubo incluso ou exserto; disco nectarífero ausente; estemonozone presente. Fruto legume, valvas falcadas a espiraladas, plano-compresso, margens estreitas, valvas cartáceas, endocarpo geralmente avermelhado; sementes bicolores, azul e branca, sem sarcotesta, testa membranácea, pleurograma aberto ou fechado, funículo persistente.

O gênero Abarema apresenta 49 espécies distribuídas na região neotropical (Lewis \& Rico Arce 2005; Iganci \& Morim 2009). Para a Flora do Brasil, são citadas 25 espécies (BFG 2015), com centros de diversidade na Amazônia e Floresta Pluvial Atlântica (Barneby \& Grimes 1996). O gênero compreende espécies com frutos de endocarpo rubro com sementes lentiformes, bicolores e funículo persistente (Barneby \& Grimes 1996). No Espírito Santo, o gênero está representado por seis espécies que podem ser reconhecidas pelos frutos falcados ou espiralados, além das características já mencionadas.

\section{Chave de identificação das espécies de Abarema no Espírito Santo}

1. Foliólulos 11-19 pares por pina, $8-10 \mathrm{~mm}$ de comprimento. 1.5. Abarema langsdorfii

1'. Foliólulos 1-10 pares por pina, 1,2-12,4 cm de comprimento.

2. Nectários foliares verruciformes; $1-2$ foliólulos por pina

1.4. Abarema filamentosa

2'. Nectários foliares cupuliformes; 3-10 foliólulos por pina.

3. Indumento pulverulento e ferrugíneo nos ramos e nos frutos; flores homomórficas; sementes com pleurograma mediano-basal 1.3. Abarema cochliacarpos

3'. Indumento pulverulento e ferrugíneo ausente nos ramos e nos frutos; flores heteromórficas; sementes com pleurograma apical-basal.

4. Foliólulos glabrescentes; ovário seríceo 1.2. Abarema brachystachya

4'. Foliólulos glabros; ovário glabro.

5. Foliólulos com ápice arredondado a obtuso. 1.1. Abarema barnebyana

5'. Foliólulos com ápice agudo a retuso 1.6. Abarema limae 
1.1. Abarema barnebyana Iganci \& M.P. Morim, Kew Bull. 64(2): 272. 2009.

Fig. 2a-d

Arbustos 2-9 $\mathrm{m}$ alt.; ramos puberulentos a pubescentes. Folhas 3-7 pares de pinas; pecíolo 0,4-3 cm compr., pubescente; nectários foliares cupuliformes; raque 1,44-18 cm compr., pubescente; foliólulos 3-10 pares por pina, 1,2-2,2 × 0,6-1,3 $\mathrm{cm}$, obovados a rômbicos, base aguda a oblíqua, ápice arredondado a obtuso, glabros, nervura central pubescente. Unidades de inflorescências em racemos congestos, reunidas em panículas; pedúnculo 3,4-7,4 $\mathrm{cm}$, pubescente a tomentoso; raque $0,5-1 \mathrm{~cm}$ compr. Flores heteromóficas: as basais pediceladas, pedicelo ca. 1,2 mm compr.; cálice ca. 3,2 mm compr., campanulado, tomentoso; corola ca. 5,4 mm compr., campanulada, serícea; androceu ca. 15 estames, ca. $37 \mathrm{~mm}$ compr., tubo ca. $3 \mathrm{~mm}$ compr., incluso; ovário glabro. Flor terminal subséssil; cálice ca. 4 mm compr., campanulado, tomentoso; corola ca. 8,3 mm compr., campanulada, serícea; androceu ca. 19 estames, ca. $38 \mathrm{~mm}$ compr., tubo ca. 10,5 mm compr., exserto, ovário glabro. Legumes com valvas falcadas a espiraladas, glabros; sementes 5,8-8,3 $\times 5-7,4 \mathrm{~mm}$, obovadas, pleurograma apical-basal, fechado.

Material selecionado: Águia Branca, Águas Claras, 15.VIII.2007, fr., R.R. Vervloet 3203 (MBML). Linhares, Reserva Natural Vale, 29.XI.2007, fl., G.S. Siqueira 365 (CVRD).

Brasil, restrita ao Espírito Santo. A espécie está representada nas mesorregiões Litoral Norte e Noroeste, em Floresta Estacional Semidecidual e Restinga. Por apresentar poucos registros nas coleções botânicas brasileiras, esta espécie pode ser considerada de ocorrência rara (Iganci 2008). Abarema barnebyana é semelhante a A. limae, porém difere pelos foliólulos com ápice arredondado a obtuso em $A$. barnebyana, enquanto $A$. limae apresenta foliólulos com ápice agudo. A espécie também é semelhante a $A$. brachystachya pela forma dos foliólulos, número de pares de pinas e flores heteromórficas, porém A. brachystachya apresenta foliólulos maiores e ovário seríceo. Nome popular desconhecido.

1.2. Abarema brachystachya (DC.) Barneby \& J.W. Grimes, Mem. New York Bot. Gard., 74(1): 91. 1996.

Fig. 2e-h

Arbustos, 4-8 m alt.; ramos jovens pubescentes. Folhas 2-7 pares de pinas; pecíolo 1,3-4,3 cm compr., pubescente; nectários foliares cupuliformes; raque 1-2,5 cm compr., pubescente; foliólulos 3-8 pares por pina 1,5-6,8 $\times 0,8-3,5 \mathrm{~cm}$, obovados a rômbicos, base oblíqua, ápice agudo a obtuso, face adaxial glabra e abaxial glabrescente, nervura central pubescente. Unidades de inflorescências em racemos congestos, reunidos em fascículos; pedúnculo ca. $7,8 \mathrm{~cm}$, puberulento; raque ca. $1 \mathrm{~cm}$ compr. Flores heteromórficas: as basais pediceladas, pedicelo 1,5-2,6 mm compr.; cálice ca. 2,5 mm compr., campanulado, puberulento; corola ca. 8,2 mm compr., campanulada, serícea; androceu ca. 32 estames, ca. 40,5 mm compr., tubo ca. 3,5 mm compr., incluso; ovário seríceo. Flores terminais subsésseis; cálice ca. 3,9 mm, campanulado, puberulento; corola ca. $10 \mathrm{~mm}$, campanulada, serícea; androceu ca. 30 estames, ca. $35 \mathrm{~mm}$ compr., tubo ca. $7 \mathrm{~mm}$ compr., incluso; ovário seríceo. Legumes com valvas falcadas, glabros; sementes 77,4-89 × 18,8-21,6 $\mathrm{mm}$, globosas a ovadas, pleurograma apical-basal, fechado ou aberto.

Material selecionado: Linhares, Comboios, 15.V.1990, fr., P.C. Vinha 4478 (VIES). Santa Teresa, Reserva Biológica Augusto Ruschi, 20.II.2002, fl., L.J.C. Kollmann et al. 5602 (MBML).

Restrita ao Brasil, ocorrendo nos estados da Bahia, Espírito Santo, Minas Gerais, Paraná, Rio de Janeiro, Santa Catarina e São Paulo, com ocorrência comum na Floresta Atlântica (BFG 2015). No Espírito Santo, há poucos registros de ocorrência desta espécie, que se distribui nas mesorregiões Central e Litoral Norte, em Mata de Encosta e Mata de Tabuleiro. As características diagnósticas para $A$. brachystachya foram discutidas nos comentários de A. barnebyana. Coletada com flor em fevereiro e maio e com fruto em maio. Conhecida popularmente como cobi-branco.

1.3. Abarema cochliacarpos (Gomes) Barneby \& J.W. Grimes, Mem. New York Bot. Gard., 74(1): 94. 1996.

Fig. 2i-k

Árvores, ca. $8 \mathrm{~m}$ alt.; ramos pubescentes a pulverulentos, ferrugíneos. Folhas 2-3 pares de pinas; pecíolo 1-3,2 cm compr., pubescente a pulverulento, ferrugíneo; nectários foliares cupuliformes; raque $1,2-3,7 \mathrm{~cm}$ compr., pubescente a pulverulenta, ferrugínea; foliólulos 3-4 pares por pina, 3,5-4,4 $\times 1,9-3,5 \mathrm{~cm}$, elípticos a obovados, base aguda a oblíqua, ápice acuminado a cuspidado, glabros. Unidades de inflorescências em racemos capitados, isoladas ou reunidas em fascículos; pedúnculo 6-7,2 cm compr., puberulento; raque inconspícua. Flores homomórficas, subsésseis; cálice 2-2,5 mm compr., campanulado, glabro, margem ciliada; corola 6-6,5 $\mathrm{mm}$ compr., infundibuliforme, glabra, margem ciliada; androceu ca. 25 estames, ca. $15 \mathrm{~mm}$ compr., tubo ca. 4,2 mm compr., incluso; ovário glabro. 


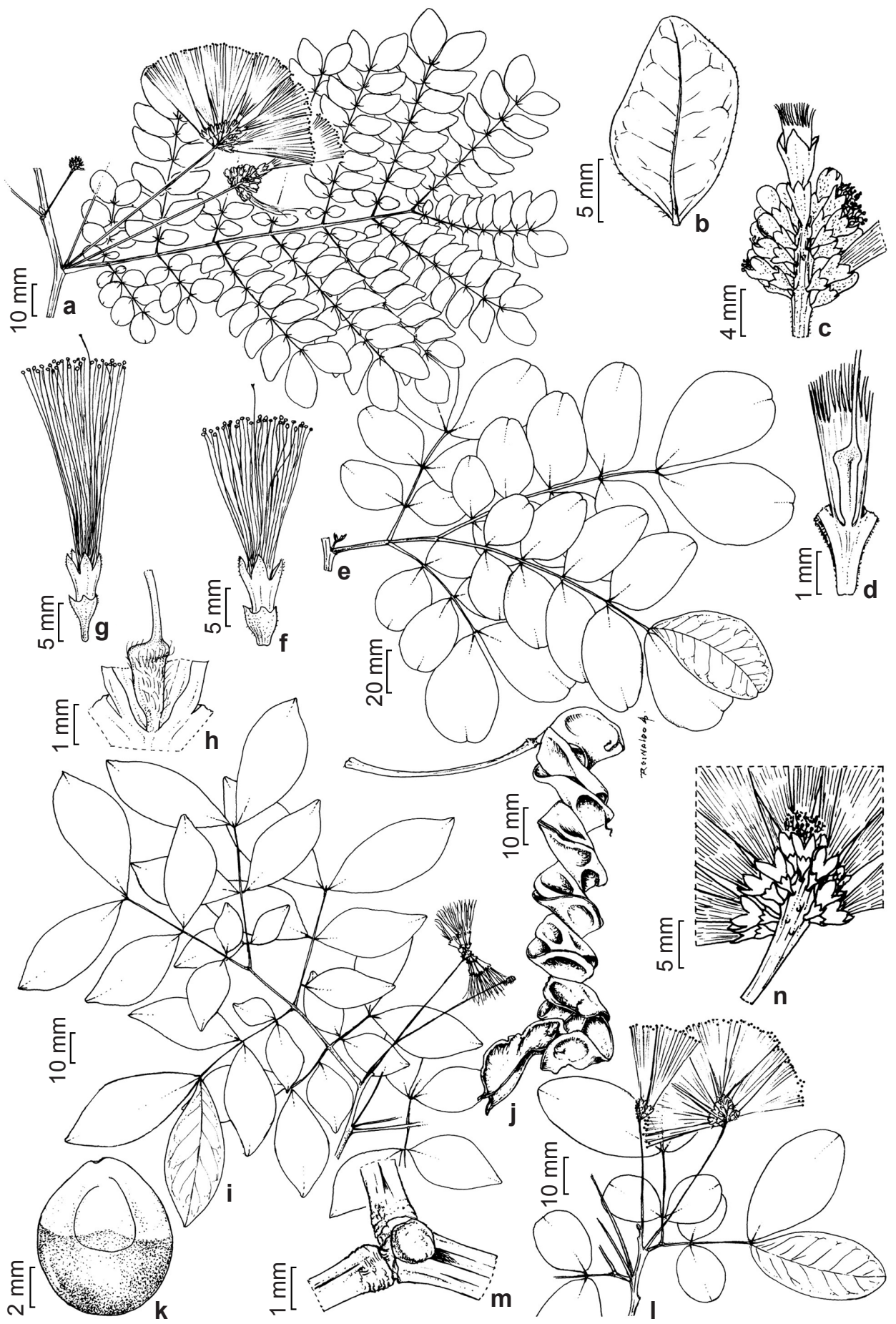

Figura 2 - a-d. Abarema barnebyana - a. ramo floral; b. foliólulo; c. inflorescência com flores heteromórficas; d. ovário. e-h. Abarema brachystachya - e. folha; f,g. flores heteromórficas; h. ovário. i-k. Abarema cochliacarpos - i. ramo floral; j. legume espiralado; k. semente; 1-n. Abarema filamentosa - 1. ramo floral; m. nectário foliar; n. inflorescência com flores heteromórficas. (d. G.S. Siqueira 365; h. L.J.C. Kollmann et al. 5602; k. A.M. Assis et al. 1322; n. R.D. Ribeiro et al. 765). Figure 2 - a-d. Abarema barnebyana - a. fertile branch; b. leaflet; c. inflorescence with heteromorphic flowers; d. ovary. e-h. Abarema brachystachya - e. leaf; f,g. heteromorphic flowers; h. ovário. i-k. Abarema cochliacarpos - i. fertile branch; j. spiraled fruit; k. semente; 1-n. Abarema filamentosa - 1. fertile branch; m. foliar nectary; n. inflorescence with heteromorphic flowers. (d. G.S. Siqueira 365; h. L.J.C. Kollmann et al. 5602; k. A.M. Assis et al. 1322; n. R.D. Ribeiro et al. 765). 
Legumes com valvas espiraladas, pulverulentas, ferrugíneas; sementes 7,3-7,7 × 5,9-6,8 mm, lentiformes a obovadas, pleurograma mediano-basal, aberto.

Material selecionado: Aracruz, Vila do Riacho, Fazenda Manuá, 2.IV.2008, fr., R.D. Ribeiro 966 (RB). Itapemirim, Fazenda do Ouvidor, 24.I.2008, fr., A.M. Assis 1322 (MBML). Linhares, Reserva Natural Vale, 14.IX.2004, fr., D.A. Folli 4931 (CVRD). Piúma, Ilha dos Cabritos, 22.XII.1992, fr., P.C. Vinha 1408 (VIES). São Mateus, Bairro Liberdade, 10.III.2007, fl., A.O. Giaretta 40 (VIES).

Restrita ao Brasil, apresenta ampla distribuição na porção leste do Brasil ocorrendo em Alagoas, Bahia, Ceará, Espírito Santo, Minas Gerais, Paraíba, Pernambuco, Rio de Janeiro, Rio Grande do Norte, São Paulo e Sergipe, em Cerrado e Floresta Atlântica (Iganci \& Morim 2012; BFG 2015). No Espírito Santo, a espécie é comum no Litoral Norte, em Mata de Tabuleiro e Restinga, com poucos registros na mesorregião Sul, em Floresta Estacional Semidecidual. Abarema cochliacarpos distinguese das demais espécies do gênero encontradas no Espírito Santo por apresentar indumento ferrugíneo pulverulento nos ramos e nas valvas do fruto, foliólulos glabros de ápice acuminado a cuspidado, inflorescência do tipo racemo capitado, com raque inconspícua, e sementes com pleurograma mediano-basal. Coletada com flor em março e novembro e, com fruto, em janeiro, abril, maio e de setembro a dezembro. Conhecida popularmente como ingá-preto.

1.4. Abarema filamentosa (Benth.) Pittier, Trab. Com. Venezuela 2: 86. $1846 . \quad$ Fig. 21-n

Árvores a arbustos, 2-8 m alt.; ramos puberulentos. Folhas (1-)2-3 pares de pinas; pecíolo 0,3-1,6 cm compr., puberulento; nectários foliares verruciformes, orbiculares; raque 0,8-3,3 cm compr., puberulenta; foliólulos 1-2 pares por pina, 3-8,5 × 2,3-4,6 cm, elípticos a obovados, base aguda a oblíqua, ápice obtuso, retuso ou arredondado, glabros. Unidades de inflorescências em racemo laxo, isoladas ou reunidas em fascículos; pedúnculo 3,4$6,8 \mathrm{~cm}$, puberulento; raque $1-1,6 \mathrm{~cm}$ compr. Flores herteromórficas: as basais pediceladas, pedicelo 1-2 mm compr.; cálice 1,6-3 mm compr., campanulado, puberulento, principalmente nas lacínias; corola 2,5-9 mm compr., campanulada, puberulenta, principalmente nas lacínias; androceu 23-30 estames, 24-36,8 mm compr., tubo 1,3-6,4 mm compr., incluso; ovário glabro. Flor terminal séssil; cálice 2,5-4 mm compr., tubuloso, puberulento; corola 8-11 mm compr., campanulada, puberulenta, principalmente nas lacínias; androceu 35-55 estames,
32-38,5 mm compr., tubo 11-15 mm compr., exserto; ovário glabro. Legumes com valvas espiraladas, glabros; sementes 7-9,6 × 6,2-9 mm, obovadas, pleurograma apical-basal, fechado.

Material selecionado: Conceição da Barra, Pontal do Sul, 12.III.2007, fl., R.D. Ribeiro 765 (RB). Linhares, Reserva Natural Vale, 14.IV.1997, fl., D.A. Folli, 2994 (CVRD). São Mateus, Bairro Liberdade, 14.IV.2007, fr., M.B. Faria 40 (VIES).

Restrita ao Brasil, ocorre na Floresta Atlântica de Alagoas, Bahia, Espírito Santo, Paraíba, Pernambuco, Rio Grande do Norte e Sergipe, em formações de restinga aberta, bem como em formações arbóreas e fechadas, apresentando grande variação morfológica entre as populações (Iganci \& Morim 2012; BFG 2015). No Espírito Santo, possui ampla distribuição na mesorregião Litoral Norte, em Mata de Tabuleiro e Restinga. Abarema filamentosa é reconhecida por apresentar os maiores foliólulos (3-8,5 × 2,3-4,6 cm) dentre as demais espécies de Abarema coletadas no Espírito Santo, apenas 1-2 pares de foliólulos por pina e nectários foliares verruciformes. Coletada com flor de março a maio e com fruto em fevereiro, abril, junho, agosto e de outubro a dezembro. Conhecida popularmente como olho-de-pomba.

1.5. Abarema langsdorfii (Benth.) Barneby \& J.W. Grimes, Mem. New York Bot. Gard., 74(1): 95. 1996.

Fig. 3a-c

Árvores, ca. $6 \mathrm{~m}$ alt.; ramos pubescentes. Folhas 5-6 pares de pinas; pecíolo 1,6-2 cm compr., pubescente; nectários foliares cupuliformes; raque 4-5,6 cm compr., pubescente; foliólulos 11-19 pares por pina, 8-10 × 2-4 mm, oblongo-lanceolados, base oblíqua, ápice agudo, face adaxial glabra e abaxial glabra a glabrescente, nervura central pubescente. Unidades de inflorescências em racemo laxo, isoladas ou reunidas em fascículos; pedúnculo 6-8 cm compr., tomentoso; raque $1-1,7 \mathrm{~cm}$ compr. Flores homomórficas, sésseis a pediceladas, pedicelo até 1,2 mm compr.; cálice 3,8-4,2 mm compr., campanulado, seríceo; corola 7,6 × 8,7 mm compr., campanulada, serícea; androceu 30-32 estames, ca. 30 mm compr., tubo ca. 6,3 mm compr., exserto; ovário glabro, ápice pubescente. Legumes com valvas espiraladas, puberulentos; sementes não observadas.

Material selecionado: Domingos Martins, Alto Paraju, 8.II.2011, fl., L.C. Vargas \& J. Breda (VIES 13404). Linhares, Reserva Natural Vale, 2.XII.1972, fl., J. Spada 114 (RB); Santa Teresa, Reserva Biológica Augusto Ruschi, 29.I.2002, fl., L.J.C. Kollmann 5388 (MBML). Serra, APA do Mestre Álvaro, 10.III.2012, fr., L.A. Silva 99 (VIES).

Restrita ao Brasil, ocorre na Bahia, Espírito Santo, Minas Gerais, Paraná, Rio de Janeiro, Rio 


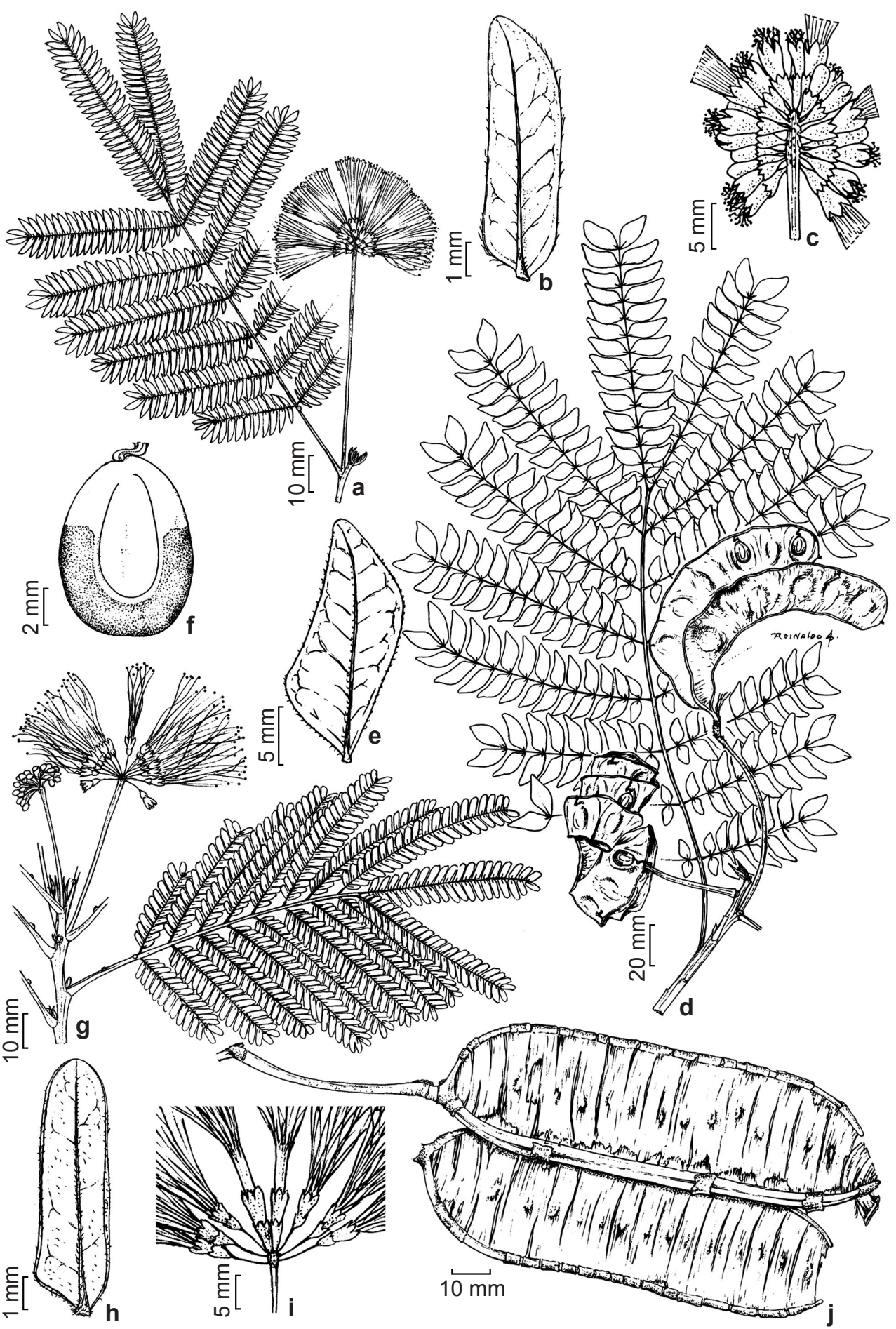

Figura 3 - a-c. Abarema langsdorfii - a. ramo floral; b. foliólulo; c. inflorescência com flores homomórficas. d-f. Abarema limae - d. ramo com frutos falcados; e. foliólulo; f. semente. g-j. Albizia pedicelaris - g. ramo floral; h. foliólulo; i. inflorescência com flores heteromórficas; j. folículo. (c. L.C. Vargas \& J. Breda VIES 13404; f. C.L. Dalmonech \& T.F. Sagrillo 53; i. A.A. Luz da 285; J.R. Stehmann 4704).

Figure 3 - a-c. Abarema langsdorfii - a. fertile branch; b. leaflet; c. inflorescence with homomorphic flowers. d-f. Abarema limae - d. branch with sickle fruits; e. leaflet; f. seed. g-j. Albizia pedicelaris - g. fertile branch; h. leaflet; i. inflorescence with heteromorphic flowers; j. follicle. (c. L.C. Vargas \& J. Breda VIES 13404; f. C.L. Dalmonech \& T.F. Sagrillo 53; i. A.A. Luz da 285; J.R. Stehmann 4704). 
Grande do Sul, Santa Catarina e São Paulo, em Cerrado e Floresta Atlântica, predominando no Brasil Atlântico e atingindo o limite sul de distribuição do gênero, no norte do Rio Grande do Sul (Iganci \& Morim 2012; BFG 2015). No Espírito Santo, a espécie foi encontrada tanto no Litoral Norte, em Mata de Tabuleiro, quanto no interior da mesorregião Central, em Mata de Encosta. Abarema langsdorfii é facilmente identificada no gênero por apresentar foliólulos diminutos $(8-10 \times 2-4 \mathrm{~mm})$, numerosos, inflorescências congestas e flores homomórficas. Coletada com flor em dezembro e janeiro e com fruto em março. Nome popular desconhecido.

1.6. Abarema limae Iganci \& M.P. Morim, Kew Bull. 64(2): 276. 2009.

Fig. 3d-f

Árvores, ca. $8 \mathrm{~m}$ alt.; ramos pubescentes. Folhas 6-9 pares de pinas; pecíolo 0,5-5,8 cm compr., pubescente; nectários foliares cupuliformes; raque 8-12,4 cm compr., pubescente; foliólulos 6-10 pares por pina, 1,6-2,5 × 1-1,6 cm, rômbicos, base oblíqua, ápice agudo a retuso, glabros, nervura central pubescente. Unidades de inflorescências em racemo congesto, reunidas em fascículos; pedúnculo 7-10,6 cm compr., pubescente; raque 0,5-1 cm compr. Flores heteromórficas: as basais pediceladas, pedicelo 4,1-5 mm compr.; cálice ca. $3 \mathrm{~mm}$ compr., campanulado, pubescente; corola ca. 6,4 mm compr., campanulada, serícea; androceu 25-32 estames, ca. 32,5 mm compr., tubo 1,9 mm compr., incluso; ovário glabro. Flor terminal subséssil; cálice 3-3,8 mm compr., campanulado, pubescente; corola 10-12 mm compr., campanulada, serícea; estames ca. 30, ca. 37,5 mm compr., tubo ca. 14,5 mm compr., exserto; ovário glabro. Legumes com valvas falcadas a espiraladas, puberulentos; sementes 7,2-9,4 × 6,3-8 $\mathrm{mm}$, obovadas, pleurograma apical-basal, fechado. Material selecionado: Águia Branca, Córrego do Trinta, 25.IV.2006, fr., V. Demuner et al. 2183 (MBML). Aracruz, Picuã, 4.VI.2011, fr., C.L. Dalmonech \& T.F. Sagrillo 53 (MBML). Guarapari, Rod. do Sol Km 24, 4.XI.1991, fl., P.C. Vinha 1370(VIES). Linhares, Comboios, 7.I.1992, fl., O.J. Pereira et al. 2510 (VIES). Santa Leopoldina, Colina Verde, 29.XI.2007, fr., V. Demuner et al. 4617 (MBML).

Restrita ao Brasil, ocorre nos estados do Espírito Santo e Rio de Janeiro, em Floresta Atlântica
(Iganci \& Morim 2012; BFG 2015). Possui áreas de distribuição geográficas comuns à $A$. barnebyana em seu limite Norte e são, portanto, espécies simpátricas (Iganci 2008). No Espírito Santo, a espécie foi pouco coletada, geralmente, com apenas um registro para municípios das mesorregiões Central, Litoral Norte e Noroeste, em Floresta Estacional Semidecidual, Mata de Encosta e Restinga. A ocorrência em vegetação de Restinga amplia a distribuição observada por Iganci \& Morim (2012) para o Domínio Atlântico. Os caracteres diagnósticos de Abarema limae foram discutidos nos comentários de $A$. barnebyana. Coletada com flor em janeiro e novembro e com fruto de março a junho, agosto e novembro. Nome popular desconhecido.

\section{Albizia Durazz., Mag. Tosc., 3(4): 13-14. 1772.}

Árvores, ramos inermes; gemas peroladas ausentes; estípulas caducas. Folhas bipinadas, pinas 4-14 pares; nectários foliares sésseis a estipitados, caliciformes, capitados, cupuliformes ou pateliformes, no pecíolo e, geralmente, entre pares de pinas e de foliólulos; parafilídeos presentes; venação do foliólulo palminérvea ou peninérvea. Unidades de inflorescências capituliformes ou umbeliformes, reunidas em fascículos ou panículas, axilares ou terminais; brácteas caducas. Flores heteromórficas, 5-6 meras; estames 10-30, monocolores, alvos, tubo incluso ou exserto; disco nectarífero presente ou ausente. Fruto legume ou folículo, reto, plano compresso, margens estreitas ou espessadas; sementes monocolores, testa óssea, pleurograma aberto ou fechado.

Albizia possui de 120 a 140 espécies. Apresenta distribuição pantropical, com maior diversidade nos Neotrópicos, África e sudeste da Ásia. No Brasil, ocorrem 10 espécies, sendo três endêmicas (BFG 2015). O gênero é considerado como polifilético, com base em estudos filogenéticos (Barneby \& Grimes 1996; Luckow et al. 2003). É caracterizado por apresentar ramos inermes, folhas bipinadas, flores heteromórficas, fruto reto sem deiscência elástica, sementes monocolores e testa óssea (Barneby \& Grimes 1996). No Espírito Santo, está representado por apenas duas espécies, $A$. pedicellaris e $A$. polycephala.

\section{Chave de identificação das espécies de Albizia no Espírito Santo}

1. Foliólulos peninérveos; unidades de inflorescências tipo corimbo ou umbela, isoladas ou fasciculadas; fruto folículo, lenhoso, com suturas transversais 2.1. Albzia pedicellaris

1'. Foliólulos palminérveos; unidades de inflorescências capituliformes reunidas em panículas; fruto legume, cartáceo, reticulado 2.2. Albizia polycephala 
2.1. Albizia pedicellaris (DC.) L. Rico, Novon 9(4): 555. 1999.

Fig. $3 g-j$

Árvores, 8-28 m alt.; ramos jovens tomentosos. Folhas $4-10$ pares de pinas, pecíolo 1,7-4 cm compr., tomentoso; nectários foliares sésseis a estipitado, capitados a caliciformes; raque 2,3-10,7 cm compr., tomentosa; foliólulos 15-27 pares por pina, 6-14 × 2-6 mm, oblongos a obovados, base oblíqua, ápice obtuso, face adaxial glabra, estrigosa na margem e face abaxial estrigosa, principalmente na nervura central, venação peninérvea. Unidades de inflorescências em corimbo ou umbela, isoladas ou reunidas em fascículos, axilares ou terminais; pedúnculo $2-4,3 \mathrm{~cm}$ compr., tomentoso; raque $0,2-0,3$ $\mathrm{mm}$ compr. Flores basais pediceladas, pedicelo 2-6,8 mm compr.; cálice $2-2,5 \mathrm{~mm}$ compr., campanulado, seríceo; corola 5,8-7 mm compr., campanulada, serícea; androceu 13-18 estames, 30-35 mm compr., tubo $2,3-3 \mathrm{~mm}$ compr., incluso; ovário glabro, ápice puberulento. Flores centrais, geralmente 2, subsésseis, cálice 2,8-4 mm compr., tubuloso, seríceo; corola 9-11,3 mm, campanulada, serícea; androceu ca. 30 estames, 27-28,5 mm compr., tubo $15-17 \mathrm{~mm}$ compr, exserto; disco nectarífero ausente; ovário glabro, ápice puberulento. Folículos 7-12,3 × 2-3,5 cm, oblongos, retos, lenhosos, com suturas transversas, puberulentos, margens espessadas; sementes 7-7,6 $\times 3,6-4,4 \mathrm{~mm}$, oblongas a ovadas, pleurograma apical-basal, fechado.

Material selecionado: Anchieta, Floresta de Tabuleiro, 29.I.2010, fr., J.M.L. Gomes \& R.T. Valadares 3626 (VIES). Aracruz, área da Aracruz Celulose S.A., 18.IV.2005, fl., A.A. Luz da 285 (CVRD). Conceição da Barra, Reserva Biológica do Córrego Grande, 28.VIII.2012, fr., T.B. Flores \& G.O. Romão 1251 (VIES). Linhares, Reserva Natural Vale, 7.II.2007, fr., J.R. Stehmann 4704 (CVRD). Serra, Manguinhos, 14.II.2011, fr., S.S. Marques (VIES 27734).

Distribui-se pela América do Sul na Bolívia, Brasil, Colômbia, Equador, Guiana, Guiana Francesa, Peru, Suriname e Venezuela (Barneby \& Grimes 1996). No Brasil, ocorre no Acre, Alagoas, Amapá, Amazonas, Bahia, Espírito Santo, Maranhão, Mato Grosso, Mato Grosso do Sul, Minas Gerais, Pará, Paraná, Pernambuco, Rio de Janeiro, Rio Grande do Norte, Rondônia, Roraima, São Paulo e Tocantins, em Floresta Amazônica, Cerrado e Floresta Atlântica (BFG 2015). No Espírito Santo, foi registrada no Litoral Norte, em Mata de Tabuleiro e Restinga, bem como, em menor frequência, na mesorregião Central, também em vegetação de Restinga.
Albizia pedicellaris é muito semelhante à $A$. polycephala quanto ao número de pares de pinas e forma dos foliólulos, porém, diferencia-se por apresentar foliólulos peninérveos, nectários foliares capitados a caliciformes, unidades de inflorescência tipo umbela ou corimbosas, fruto folículo lenhoso com suturas transversais e sementes com pleurograma apical-basal, enquanto o segundo táxon apresenta foliólulos palminérveos, nectários foliares cupuliformes a pateliformes, unidades de inflorescência sempre capituliformes reunidas em longas panículas, frutos legumes e sementes com pleurograma central. Coletada com flor em março, abril e outubro e com fruto de janeiro a março, julho e agosto. Conhecida popularmente como jueirana-branca.

2.2. Albizia polycephala (Benth.) Killip ex Record, Trop. Woods 63: 6. 1940.

Fig. 4a-d

Árvores, 6-15 m alt.; ramos jovens tomentosos. Folhas 6-14 pares de pinas, pecíolo 2,3-4,7 cm compr., tomentoso; nectários foliares sésseis, cupuliformes ou pateliformes; raque 7-15 $\mathrm{mm}$ compr., tomentosa; foliólulos 15-25 pares por pina, 5-10 × 2-4 cm, oblongos a obovados, base truncada a oblíqua, ápice agudo, face abaxial estrigosa e face adaxial glabra, estrigosa na margem, venação palminérvea. Unidades de inflorescências capituliformes reunidas em panículas, terminais; pedúnculo 1-1,6 cm compr., tomentoso, raque $0,2-0,3 \mathrm{~cm}$ compr. Flores basais subsésseis; cálice ca. 1,5-2 mm compr., campanulado, puberulento; corola 3,3-3,5 mm compr., campanulada, serícea; androceu ca. 10 estames, $10-12 \mathrm{~mm}$ compr., tubo 1,7-2 $\mathrm{mm}$ compr., incluso; ovário glabro. Flor central subséssil; cálice 2,5-2,6 mm compr., tubuloso, puberulento; corola 5-5,5 mm, campanulada, serícea; androceu 13-14 estames, 10,5-14 $\mathrm{mm}$ compr., tubo 6,5-7 $\mathrm{mm}$ compr, exserto; disco nectarífero presente; ovário glabro. Legumes 7,7-18 × 2,2-3,5 cm, estreitoelípticos, cartáceos, reticulados, glabrescentes, margens estreitas; sementes 7-8,5 × 5-7,1 mm, oblongas, pleurograma central.

Material selecionado: Águia Branca, Águas Claras, 2.II.2006, fl., L.F.S. Magnago 670 (MBML). Aracruz, Retiro, 5.V.1992, fr., O.J. Pereira et al. 7653 (VIES). Linhares, Reserva Natural Vale, 2.VIII.1990, fr., D.A. Folli 1330 (CVRD). Laranja da Terra, estrada Laranja da Terra a Sobrero, 15.XII.1991, f1., D.A. Folli 1531 (CVRD). Marilândia, Liberdade, 27.IX.2006, fr., L.F.S. Magnago 1440 (MBML). Nova Venécia, Serra de Cima, 25.IV.2008, fr., A.M. Assis 1505 (MBML). Presidente Kennedy, São Salvador, 2.III.1993, fl., 


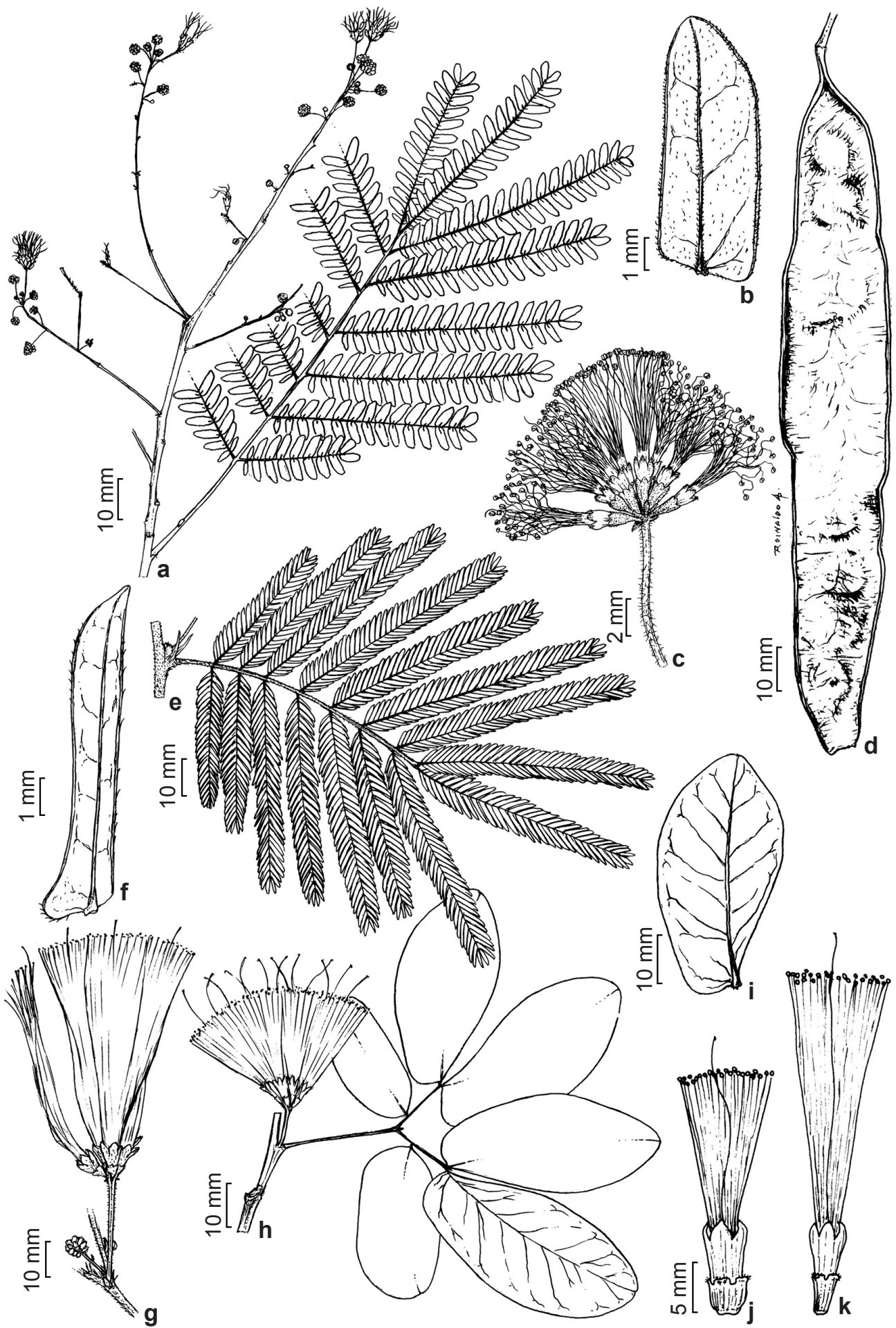

Figura 4 - a-d. Albizia polycephala - a. ramo floral; b. foliólulo; c. inflorescência com flores heteromórficas; d. legume. e-g. Calliandra bella - e. folha; f. foliólulo; g. inflorescência. h-k. Calliandra harrisii - h. ramo floral; i. foliólulo; j,k. flores heteromórficas. (c. V. Souza de 475; d. D.A. Folli 1330; g. V. Demuner 3843; k. L.J.C. Kollmann et al. 9338). Figure $4-\mathrm{a}$-d. Albizia polycephala $-\mathrm{a}$. fertile branch; $\mathrm{b}$. leaflet; c. inflorescence with heteromorphic flowers; d. legume. e-g. Calliandra bella - e. leaf; f. leaflet; g. inflorescence. h-k. Calliandra harrisii - h. fertile branch; i. leaflet; j,k. heteromorphic flowers. (c. V. Souza de 475; d. D.A. Folli 1330; g. V. Demuner 3843; k. L.J.C. Kollmann et al. 9338). 
J.M.L. Gomes 1829 (VIES). Santa Leopoldina, Morro Agudo, 14.IX.2006, fr., V. Demuner 2881 (MBML). Vila Velha, Parque Ecológico Espera Maré, Morro da Mantegueira, 6.IV.1993, fl., V. de Souza 475 (VIES). Vitória, Goiabeiras, Campus da UFES, 20.V.1992, fr., J.M.L. Gomes 1692 (VIES).

Restrita ao Brasil, oocorre em Alagoas, Bahia, Ceará, Espírito Santo, Goiás, Mato Grosso do Sul, Minas Gerais, Paraíba, Paraná, Piauí, Pernambuco, Rio de Janeiro, Rio Grande do Norte, Rio Grande do Sul, Santa Catarina, São Paulo e Sergipe, em Caatinga, Cerrado e Floresta Atlântica (Barneby \& Grimes 1996; BFG 2015). No Espírito Santo, a espécie está representada nas quatro mesorregiões, em Floresta Estacional Semidecidual, Mata de Encosta, Mata de Tabuleiro e Restinga. Os caracteres diagnósticos de Albizia polycephala foram discutidos nos comentários de A. pedicellaris. Coletada com flor de dezembro a março e com fruto de janeiro a maio e de julho a setembro. Conhecida popularmente como monjolo.

3. Calliandra Benth., J. Bot. (Hooker) 2(11): 138141. 1840.

Arbustos; ramos inermes; estípulas persistentes, gemas peroladas ausentes. Folhas bipinadas, pinas 1-8 pares; nectários foliares ausentes; parafilídios ausentes ou presentes. Unidades de inflorescências capituliformes, isoladas ou reunidas em fascículos; brácteas caducas ou persistentes. Flores homomórficas ou heteromórficas, 4-6-meras; estames 29-75, monocolores ou bicolores, tubo incluso ou exserto; disco nectarífero ausente; estemonozone presente. Fruto legume, plano compresso, margens estreitas ou expandidas, lenhoso, deiscência elástica; sementes monocolores, pleurograma presente.

O gênero Calliandra apresenta cerca de 135 espécies neotropicais, com área de distribuição estendendo-se do sul dos Estados Unidos ao Uruguai, sendo que um dos principais centros de diversidade está no Nordeste do Brasil, onde estão representadas 66 espécies, principalmente no Cerrado e Campo Rupestre, das quais 31 são endêmicas da Bahia (Barneby 1998; Lewis et al. 2005). Calliandra inclui espécies do clado Mimosoide com androceu polistêmone e monadelfo, legume com deiscência longitudinal elástica a partir do ápice e valvas com margens espessadas (Barneby 1998; Souza \& Queiroz 2004). Estudos moleculares sustentam Calliandra como grupo monofilético e irmão de Zapoteca, com quem compartilha as principais características diagnósticas (Souza 2013). No Brasil, ocorrem 74 espécies, sendo 59 endêmicas (BFG 2015). Está representado no Espírito Santo por apenas duas espécies, C. harrisii e C. bella.

\section{Chave de identificação das espécies de Calliandra no Espírito Santo}

1. Foliólulos 1 1/2 par por pina; flores heteromórficas; filetes bicolores, alvos na base e distalmente avermelhados 3.2. Calliandra harrisii

1. Foliólulos 35-41 pares por pina; flores homomórficas; filetes alvos. 3.1. Calliandra bella

3.1. Calliandra bella Benth., London J. Bot. 3: 110, 1844.

Fig. $4 \mathrm{e}-\mathrm{g}$

Arbustos, $6 \mathrm{~m}$ alt. Estípulas 3,3-4 $\mathrm{mm}$ compr., lanceoladas a lineares. Folhas 8 pares de pinas, pecíolo 1,2-1,4 cm compr., tomentoso; raque 6,6-7,3 cm compr., tomentosa; foliólulos 35-41 pares por pina, parafilídios ausentes, $5-8 \times 2 \mathrm{~mm}$, estreitamente oblongos, base assimetricamente auriculada, ápice agudo, face adaxial glabra e face abaxial glabrescente. Unidades de inflorescências reunidas em fascículos, axilares ou terminais; pedúnculo 2,3-3 cm compr., tomentoso, bracteado; brácteas 2-2,5 mm compr., cuculadas a lanceoladas, caducas. Flores homomórficas, subsésseis; cálice 2,8-3 mm compr., campanulado, esparso-seríceo; corola 8,6-9 mm compr., campanulada, serícea; androceu 29-47 estames, filetes alvos, ca. $60 \mathrm{~mm}$ compr., tubo ca. $5 \mathrm{~mm}$ compr., incluso; ovário glabro, ápice velutino. Legumes não observados. Material selecionado: Governador Lindemberg, Pedra de Santa Luzia, 26.IV.2007, fl., V. Demuner 3843 (MBML).

Restrita ao Brasil, ocorre na Bahia, Espírito Santo e Minas Gerais, na Caatinga, Cerrado e Floresta Atlântica (Fernandes 2011; BFG 2015; Dutra et al. 2015). No Espírito Santo, foi registrada em apenas uma localidade da mesorregião Noroeste, em Mata de Encosta. Calliandra bella difere de $C$. harrisii pelo número elevado de foliólulos (35 a 41), pedúnculo bracteado, flores homomórficas e estames alvos. Calliandra harisii apresenta 1 $1 / 2$ par de foliólulos por pina, pois a juga basal da 
pina é formada por apenas um foliólulo; pedúnculo ebracteado; flores heteromórficas; disco nectarífero; filetes bicolores, distalmente avermelhados. Coletada com flor em abril. Nome popular desconhecido.

3.2. Calliandra harrisii (Lindl.) Benth., London J. Bot. 3: 95, 1844.

Fig. $4 \mathrm{~h}-\mathrm{k}$

Arbustos, 2-4 m alt. Estípulas 1,5-2,5 mm compr., deltóides. Folhas 1 par de pina, pecíolo 1,8$2,6 \mathrm{~cm}$ compr., glabrescente; raque ausente; foliólulos $11 / 2$ par por pina, parafilídios presentes, 37-62 $\times 17-30 \mathrm{~cm}$, elípticos a obovados, base oblíqua, ápice obtuso a arredondado, glabros. Unidades de inflorescências isoladas, axilares; pedúnculo 8-16 mm compr., pubescente, ebracteado; brácteas ca. 1 mm compr., panduriformes. Flores heteromórficas: as basais subsésseis; cálice 3,3-3,6 mm compr., campanulado, glabrescente; corola 7,5-9,5 mm compr., estreitamente campanulada, glabrescente, lacínias avermelhadas; androceu ca. 24 estames, filetes distalmente avermelhados, ca. 35-53 mm compr., tubo 4,6-10,3 mm compr., incluso; ovário glabro. Flor central séssil; cálice 3,2-3,4 mm compr., campanulado, glabro; corola 8,2-12,5 mm compr., estreitamente campanulada, glabra; androceu ca. 75 estames, filetes distalmente avermelhados, ca. 21,8 mm compr., incluso; ovário glabro. Legumes 10-12 $\times$ 0,3-0,4 cm compr., estriados, 4-angulares, lineares, glabros; sementes não observadas.

Material selecionado: Marilândia, Liberdade, 12.VI.2007, fr., $V$. Demuner 4218 (MBML). Santa Leopoldina, Rio Claro, 28.IX.2007, fl., J. Rossini 677 (MBML). Santa Teresa, Vargem Alegre, Cachoeira do Madalão, 29.IX.2006, fl., L.J.C. Kollmann et al. 9338 (MBML).

Ocorre na América Centro-Oriental, Bolívia, Brasil e Paraguai (Barneby 1998). No Brasil é encontrada na Bahia, Espírito Santo e Rio de Janeiro, em Caatinga, Cerrado e Floresta Atlântica (BFG 2015; Dutra et al. 2015). No Espírito Santo, foram poucos os registros de ocorrência da espécie nas mesorregiões Central e Noroeste, em Floresta Estacional Semidecidual e Mata de Encosta. Os caracteres que distinguem $C$. harrisii e $C$. bella foram discutidos anteriormente. Coletada com flor em julho e setembro e com fruto em junho. Nome popular desconhecido.

4. Chloroleucon (Benth.) Britton \& Rose ex Record, Trop. Woods 10: 24. 1927

Árvores; ramos armados, sem cicatrizes de braquiblastos; gemas com escamas peroladas; estípulas ausentes ou caducas. Folhas bipinadas, pinas 3 pares; nectários foliares sésseis a subsésseis, cupuliformes a pateliformes, no pecíolo e, geralmente, entre pares de foliólulos; parafilídeos presentes. Unidades de inflorescências capituliformes reunidas em panículas ou isoladas, axilares; brácteas caducas. Flores homomórficas ou heteromórficas, 5-meras; estames monocolores, tubo incluso ou exserto. Fruto legume, levemente falcado a espiralado, planocompresso, margens estreitas, glabro. Semente com testa óssea, pleurograma apical-basal, aberto.

Chloroleucon apresenta cerca de 10 espécies, de distribuição neotropical (Lewis \& Rico Arce. 2005). No Brasil, está representado por sete espécies (BFG 2015), sendo que a maior parte destas ocorre em ambientes sazonalmente secos. É caracterizado, principalmente, por apresentar ramos armados (espinescentes) e gemas envolvidas por escamas peroladas (Barneby \& Grimes 1996). No Espírito Santo, o gênero está representado por apenas duas espécies, C. extortum e C. tortum.

\section{Chave de identificação das espécies de Chloroleucon no Espírito Santo}

1. Folhas com pecíolo 1-2,3 cm compr.; raque pubescente; flores homomórficas; fruto levemente falcado, moniliforme. 4.1. Chloroleucon extortum

1. Folhas com pecíolo 2,3-5 mm compr.; raque glabra; flores heteromórficas, fruto espiralado, não monilifome 4.2. Chloroleucon tortum

4.1. Chloroleucon extortum Barneby \& J.W. Grimes, Mem. New York Bot. Gard. 74(1): 142. 1996.

Fig. 5a-d

Árvores, 6-23 m alt. Folhas 3 pares de pinas; pecíolo 2,3-5 $\mathrm{mm}$ compr., pubescente; nectários foliares cupuliformes a pateliformes; raque 3-3,7 cm compr., pubescente; foliólulos
6-13 pares por pina, 5-15 × 4-13 mm, oblongos a ovados, base oblíqua, ápice acuminado a agudo, glabros. Unidades de inflorescências capituliformes, reunidas em panículas, axilares ou terminais; pedúnculo 1,2-2,2 cm compr., pubescente, bracteado; raque ca. $0,5 \mathrm{~cm}$ compr. Flores homomórficas, pediceladas, pedicelo 1,2-2 


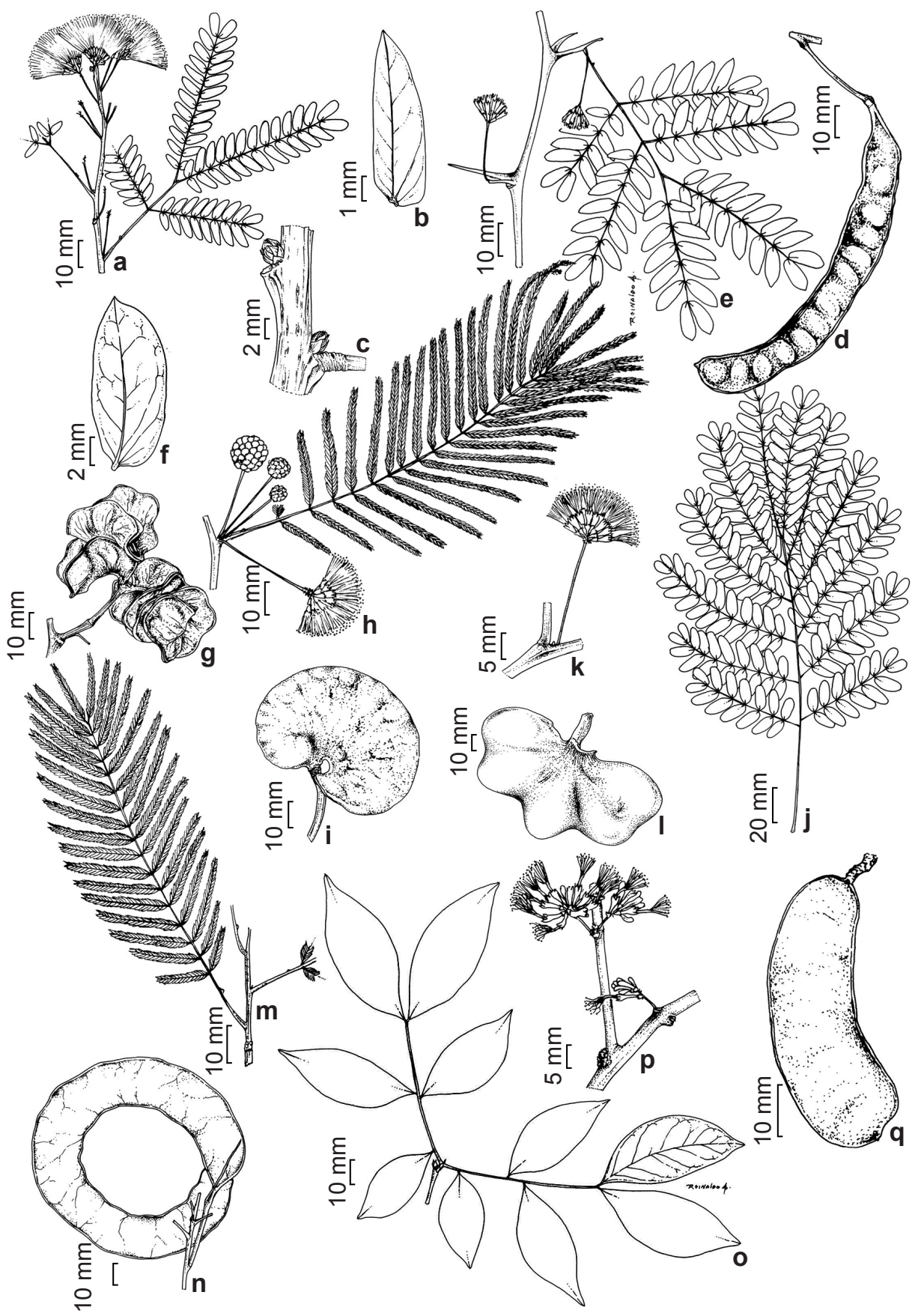

Figura 5 - a-d. Chloroleucon extortum - a. ramo floral; b. foliólulo; c. gemas peroladas; d. legume falcado. e-g. Chloroleucon tortum - e. ramo floral; f. foliólulo; g. legume espiralado. h,i. Enterolobium glaziovii - h. ramo floral; i. legume nucóide. j-1. Enterolobium monjolo - j. folha; k. inflorescência; 1. legume bacóide. m,n. Leucochloron incuriale - m. ramo; n. folículo falcado. o-q. Zygia latifolia var. glabrata - o. folha; p. ramo floral; q. folículo. (a. D.A. Folli 6544; d. D.A. Folli 6241; g. D.A. Folli 3168; h. J. Spada 107; i. D.A. Folli 5335; k. A.A. Luz 465; 1 . O.J. Pereira \& E. Espindula 6484; n. D.A. Folli 6573; p. A.A. da Luz 500; q. O.J. Pereira et al. 3383).

Figure 5 - a-d. Chloroleucon extortum - a. fertile branch; b. leaflet; c. pearly gems; d. falcate fruit. e-g. Chloroleucon tortum - e. fertile branch; f. leaflet; g. spiraled fruit. h,i. Enterolobium glaziovii - h. fertile branch; i. nucoid fruit. j-1. Enterolobium monjolo - j. leaf; k. inflorescence; 1. bacoid fruit. m,n. Leucochloron incuriale - m. branch; n. falcate fruits. o-q. Zygia latifolia var. glabrata - o. leaf; $\mathrm{p}$. fertile branch; q. follicle. (a. D.A. Folli 6544; d. D.A. Folli 6241; g. D.A. Folli 3168; h. J. Spada 107; i. D.A. Folli 5335; k. A.A. Luz 465; 1. O.J. Pereira \& E. Espindula 6484; n. D.A. Folli 6573; p. A.A. da Luz 500; q. O.J. Pereira et al. 3383). 
mm compr.; cálice 1,8-2 mm compr., campanulado, glabro, margem ciliada; corola 4-4,5 mm compr., campanulada, glabra, margem ciliada; estames 19,5-20,5 mm compr., tubo ca. $2 \mathrm{~mm}$ compr., incluso; ovário glabro. Legumes 5-10,6 × 1-1,5 $\mathrm{cm}$, levemente falcados, moniliformes; sementes ca. $6 \times 5,5 \mathrm{~mm}$, globosas.

Material selecionado: Aracruz, Comboios, 28.X.1993, fr., O.J. Pereira \& J.M.L. Gomes 4997 (VIES). Linhares, Reserva Natural Vale, 30.XI.2008, fl., D.A. Folli 6241 (CVRD). Serra, APA do Mestre Álvaro, 27.VIII.2010, fr., A. Vago et al. 14 (VIES). Sooretama, Reserva Biológica de Sooretama, 27.II.2012, fl., D.A. Folli 6848 (CVRD).

Restrita ao Brasil, ocorre nos estados da Bahia, Espírito Santo e Rio de Janeiro, em Caatinga e Floresta Atlântica (BFG 2015). No Espírito Santo, a espécie foi pouco coletada, com registros de ocorrência nas mesorregiões Central e Litoral Norte, em Mata de Encosta, Mata de Tabuleiro e Restinga. A espécie foi incluída na lista de plantas raras da flora do Brasil (Queiroz et al. 2009) e atualmente está na Lista de espécies não ameaçadas de interesse para a pesquisa e conservação por apresentar deficiência de dados (Martinelli et al. 2013), o que demostra a importância de intensificar o esforço amostral da espécie. Chloroleucon extortum distingue-se de $C$. tortum por apresentar flores homomórficas e frutos levemente falcados e moniliformes, enquanto que $C$. tortum possui flores heteromórficas e frutos espiralados. Vegetativamente são muito semelhantes. Diferenciam-se pelas dimensões do pecíolo, maiores em $C$. tortum, e pela raque pubescente de $C$. extortum. Coletada com flor em fevereiro e novembro e com fruto em agosto e setembro. Nome popular desconhecido.

4.2. Chloroleucon tortum (Mart.) Pittier, Mem. New York Bot. Gard., 74(1): 146, 1996.

Fig. 5e-g

Árvores, 12-23 m alt. Folhas 3 pares de pinas; pecíolo 1-2,3 cm compr., pubescente; nectários foliares cupuliformes; raque 2,4-3,7 cm compr., glabra; foliólulos 5-14 pares por pina, 7-15 × 2-5 mm, oblongos a obovados, base oblíqua, ápice agudo a obtuso, mucronado, glabros. Unidades de inflorescências capituliformes isoladas, axilares; pedúnculo 1,5-2 cm compr., puberulento, ebracteado; raque ca. 0,4 cm compr. Flores heteromórficas: as basais pediceladas, pedicelo ca. $2 \mathrm{~mm}$ compr.; cálice 1-2,3 $\mathrm{mm}$ compr., tubuloso, glabro; corola ca. 4,5 mm compr., infundibuliforme, glabra; estames não observados; ovário glabro. Flor central não observada. Legumes 20-25 ×0,8-1 cm, espiralados, não moniliformes, margens onduladas; sementes $6 \times 4 \mathrm{~mm}$, obovadas. Material selecionado: Cachoeiro de Itapemirim, RPPN Cafundó, 20.V.2010, fr., G. Terra 673 (CVRD). Linhares, Reserva Natural Vale, 7.V.1998, fl. e fr., D.A. Folli 3168 (CVRD).

Restrita ao Brasil, ocorre nos estados da Bahia, Distrito Federal, Espírito Santo, Goiás, Mato Grosso do Sul, Minas Gerais, Rio de Janeiro, São Paulo e Tocantins, em Cerrado e Floresta Atlântica (BFG 2015). No Espírito Santo, a espécie está representada por poucos registros na mesorregião Sul, em Floresta Estacional Semidecidual, e no Litoral Norte, como cultivada no domínio da Mata de Tabuleiro, mas sem registro na vegetação nativa. Os caracteres diagnósticos de Chloroleucon tortum foram discutidos nos comentários de C. extortum. Coletada com flor e fruto em maio. Nome popular desconhecido.

5. Enterolobium Mart., Flora 20 (2, Beibl.): 117. 1837.

Árvores; ramos inermes; gemas peroladas ausentes; estípulas caducas. Folhas bipinadas, macrofilídias ou microfilídia, pinas 2-19 pares; nectários foliares sésseis, discóides, pateliformes ou verruciformes, no pecíolo e entre pares de pinas e de foliólulos; parafilídeos presentes; venação do foliólulo inconspícua ou palminérvea. Unidades de inflorescências capituliformes, reunidas em fascículos ou panículas, axilares ou terminais; brácteas caducas. Flores homomórficas, 5-meras; estames monocolores, alvos, tubo incluso ou exserto; disco nectarífero ausente. Fruto legumes nucóide ou bacóide, auriculiformes, nigrescentes, puberulentos; sementes monocolores, testa óssea, pleurograma aberto ou fechado.

Enterolobium é um gênero neotropical com 11 espécies distribuídas do sul do México e Grandes Antilhas até o leste da Bolívia e Paraguai, norte da Argentina e Uruguai (Lewis et al. 2005). O Brasil é o seu provável centro de diversidade, onde está representado por nove espécies, das quais quatro ocorrem na Floresta Atlântica (Mesquita 1990; BFG 2015). A principal característica diagnóstica do gênero é o fruto legume bacóide ou nucóide, auriculiforme, circular, contorcido, circinado ou recurvado (Mesquita 1990). O gênero é monofilético, porém suas afinidades taxonômicas ainda não são bem resolvidas (Lewis et al. 2005). No Espírito Santo, o gênero está representado por apenas duas espécies, E. glaziovii e E. monjollo. 


\section{Chave de identificação das espécies do gênero Enterolobium no Espírito Santo.}

1. Pinas 2-9 pares, foliólulos 11-21 mm de compr.; legume bacóide 5.1. Enterolobium monjollo

1'. Pinas 14-19 pares, foliólulos 2-4,5 mm de compr.; legume nucóide. 5.2. Enterolobium glaziovii

5.1. Enterolobium glaziovii (Benth.) Mesquita, Acta Bot. Brasil. 7(2): 18. $1993 . \quad$ Fig. 5h,i Árvores, 14-34 m alt. Folhas 14-19 pares de pinas; pecíolo 1,5-2,6 cm compr., viloso; nectários sésseis, verruciformes a discóides; raque 6,5-11,5 cm compr., vilosa; foliólulos 30-64 pares por pina, $2-4,5 \times 0,8-1 \mathrm{~mm}$, lanceolados a estreitamente oblongos, base oblíqua, ápice agudo, glabros, nervação inconspícua. Unidades de inflorescências capituliformes, reunidas em fascículos, axilares; brácteas ca. 1,5 mm compr., lanceoladas, caducas. Flores subsésseis a pediceladas, pedicelo 1-1,3 mm compr.; cálice 3-3,6 mm compr., campanulado, tomentoso; corola 5-5,6 mm compr., infundibuliforme, serícea; estames 13-14,5 mm compr., tubo 3,5-4,4 mm compr., incluso; ovário seríceo. Legumes nucóides 6-8,6 $\times 3,5-4 \mathrm{~cm}$, epicarpo rugoso.

Material selecionado: Cachoeiro do Itapemirim, Bananal do Norte, 4.XI.1993, fl., G. Acácio 83 (VIES). Linhares, Reserva Natural Vale, 3.VIII.2006, fr., D.A. Folli 5335 (CVRD). Santa Leopoldina, margem do Rio Mangaraí, 22.IX.2000, fr., O.J. Pereira \& E. Espindula 6484 (VIES). Santa Teresa, 19.10.1999, fl., V. Demuner 128 (MBML).

Restrita ao Brasil, ocorre nos estados da Bahia, Espírito Santo, Minas Gerais e Rio de Janeiro, em Floresta Atlântica (BFG 2015). No Espírito Santo, a espécie foi pouco encontrada, com registro de ocorrência nas mesorregiões Central, Litoral Norte e Sul, em Mata de Encosta e Mata de Tabuleiro. Enterolobium glaziovii distingue-se de E. monjollo por apresentar foliólulos menores (2-4,5 mm de compr.), nervação inconspícua, ramos cobertos por indumento ferrugíneo-viloso e epicarpo rugoso. Enterolobium monjolo possui foliólulos maiores (11-21 mm de compr.), nervação claramente visível e peninérvea, ramos pubescentes a puberulentos e epicarpo ondulado. Coletada com flor em outubro e novembro e fruto em agosto. Nome popular desconhecido.

5.2. Enterolobium monjollo (Vell.) Benth., Flora 20 (2 Beibl.): 117. $1837 . \quad$ Fig. 5j-1

Árvores, 8-13 m alt. Folhas 5-7 pares de pinas; pecíolo 25,3-70 $\mathrm{mm}$ compr., pubescente a puberulento; nectários sésseis, pateliformes; raque 20,2-129 mm compr., pubescente a puberulenta; foliólulos 6-12 pares por pina, $11-21 \times 4-8,7$ $\mathrm{mm}$, elípticos a oblongos, par distal obovado, base obtusa a oblíqua, ápice arredondado a obtuso, face adaxial glabrescente e face abaxial esparsamente serícea. Unidades de inflorescências capituliformes, isoladas ou reunidas em fascículos, axilares; pedúnculo 12,5-30 mm compr., pubescente, bracteado; raque ca. $5 \mathrm{~mm}$ compr. Flores subsésseis a pediceladas, pedicelo 1-2 mm compr.; cálice ca. $2 \mathrm{~mm}$ compr., tubuloso, seríceo; corola ca. 4,5 mm compr., campanulada a tubulosa, serícea; estames ca. 10,5 mm compr., tubo ca. $2 \mathrm{~mm}$ compr., incluso; ovário glabro. Legumes bacóides ca. $10 \times 5,2 \mathrm{~cm}$, epicarpo ondulado.

Material selecionado: Baixo Guandu, estrada Baixo Guandú a Alto Lage, 5.IX.2007, fl., A.A. da Luz 465 (CVRD). Colatina, Barra do Santini, IX.1957, fl., J.G. Kuhlmann (RB 78305). Domingos Martins, rodovia para Rio do Galo, 11.X.1992, fl., G.G. Hatschbach 57951 (NYBG). Santa Leopoldina, 22.IX.2000, fr., O.J. Pereira \& E. Espindula 6484 (VIES). Santa Teresa, 29.XI.1948, fl., Rusch (RB 65051).

Restrita ao Brasil, ocorre nos estados da Bahia, Espírito Santo, Minas Gerais e Rio de Janeiro, em Floresta Atlântica (BFG 2015). No Espírito Santo, a espécie está representada por poucos registros em municípios das mesorregiões Central e Noroeste, em Floresta Estacional Semidecidual e Mata de Encosta. Os caracteres diagnósticos de Enterolobium monjollo foram discutidos nos comentários de E. glaziovii. Coletada com flor de setembro a novembro e com fruto em setembro. Nome popular desconhecido.

6. Leucochloron Barneby \& J.W. Grimes, Mem. New York Bot. Gard. 74(1): 130-132. 1996.

$\mathrm{O}$ gênero Leucochloron possui cinco espécies de distribuição restrita à América do Sul (Lewis et al. 2005). O Brasil é o centro de diversidade do gênero com quatro espécies em áreas de Caatinga, Cerrado e Floresta Atlântica (Barneby \& Grimes 1997; BFG 2015). Leucochloron é reconhecido pelos ramos inermes; inflorescências capituliformes globosas, axilares; flores homomórficas; frutos papiráceos, plano compressos; sementes disciformes exareoladas e presença de braquiblastos nas gemas axilares e de cicatrizes deixadas por estes no ápice de ramos 
jovens (Barneby \& Grimes 1997). É semelhante morfologicamente ao gênero Chloroleucon por ambos apresentarem gemas florais protegidas por catáfilos, porém diferencia-se pela ausência de espinhos, presença de braquiblastos e fruto do tipo folículo. No Espírito Santo, o gênero está representado apenas pela espécie Leucochloron incuriale.

6.1. Leucochloron incuriale (Vell.) Barneby \& J.W. Grimes, Mem. New. York Bot. Gard. 74(1): 134. 1996.

Fig. $5 \mathrm{~m}, \mathrm{n}$

Árvores, ca. $12 \mathrm{~m}$ alt.; ramos inermes; gemas com escamas peroladas. Estípulas ovadas, ca. 1,5 mm compr., caducas. Folhas bipinadas, microfilídias, 18-20 pares de pinas; pecíolo 1,8-2,5 mm compr., viloso; nectários sésseis a subsésseis, cupuliformes a planos, na região mediana do pecíolo; raque $8-11 \mathrm{~cm}$ compr., vilosa; foliólulos 25-46 pares por pina, parafilídeos ausentes, 2,6-3,5 × 0,6-1 mm, lanceolados, falcados, base assimetricamente truncada, ápice agudo, glabros, venação palminérvea. Flores não observadas. Folículos 14-20 × 2-2,2 cm, plano compressos, falcados, coriáceos, margens estreitas, levemente sinuosas, puberulentos; semente não observadas.

Material selecionado: Serra, APA do Mestre Álvaro, 19.III.2010, fr., D.A. Folli 6573 (CVRD).

Restrita ao Brasil, com ocorrência nos estados do Espírito Santo, Minas Gerais, Paraná, Rio de Janeiro e São Paulo, em Cerrado e Floresta Atlântica (BFG 2015; Dutra et al. 2015). No Espírito Santo, está representada por única coleta na mesorregião Central, em Mata de Encosta. A ocorrência restrita da espécie no estado é, provavelmente, devido à falta de coletas, uma vez que possui ampla distribuição nos demais estados da região Sudeste. Leucochloron incuriale pode ser reconhecido pela presença de gemas peroladas, ramos inermes e legume tipo folículo. Foram obervadas cicatrizes deixadas por braquiblastos próximos às gemas axilares. Coletada com fruto em março. Conhecida popularmente como cortiça.

7. Zygia P. Browne, Civ. Nat. Hist. Jamaica 279. 1756.

Zygia é um gênero neotropical, com 45 a 50 espécies (Lewis et al. 2005) distribuídas do México Central à Argentina, com maior distribuição na Amazônia peruana (Barneby \& Grimes 1997). No Brasil, ocorrem 19 espécies, principalmente na Floresta Amazônica, seguida pelo Cerrado,
Floresta Atlântica, Caatinga e Pantanal (BFG 2015). É caracterizado pelas inflorescências caulifloras, flores homomórficas, presença de disco nectarífero e sementes sem pleurograma (Barneby \& Grimes 1997). Pode ser confundido com Inga Miller pela semelhança das flores e pela presença dos nectários foliares, sendo diferenciada do mesmo por apresentar folhas bipinadas e inflorescências caulifloras. As folhas bipinadas são difíceis de serem reconhecidas em campo devido ao pecíolo reduzido, e pela redução de um dos foliólulos do par proximal das pinas (parafilídeo). No Espírito Santo, Zygia está representada por apenas uma espécie.

7.1. Zygia latifolia var. glabrata (Mart.) Barneby \& J.W. Grimes, Civ. Nat. Hist. Jamaica 279. 1756.

Fig. $50-\mathrm{q}$

Árvores ou arbustos, 3-8 m alt.; ramos inermes, glabrescentes a puberulentos; gemas sem escamas peroladas. Estípulas 1,5-6,3 mm compr., triangulares, caducas. Folhas bipinadas, pinas 1 par; pecíolo 1,5-6 mm compr.; nectários sésseis, cupuliformes ou pateliformes, entre os pares de pinas; foliólulos 3-5 pares por pina, foliólulo proximal 1,3-4 × 0,8-2 cm, foliólulos distais 3,5$13 \times 1,4-5,3 \mathrm{~cm}$, elípticos a oblanceolados, base oblíqua, ápice agudo a acuminado, face adaxial glabra e face abaxial glabrescente a esparsoserícea, nervura central vilosa em ambas as faces, venação peninérvea. Unidades de inflorescências capituliformes ou espiciformes, reunidas em fascículos caulifloros; pedúnculo 2-9 $\mathrm{mm}$ compr., puberulento; raque ca. $2 \mathrm{~mm}$ compr.; brácteas $0,5-$ $1 \mathrm{~mm}$ compr., cimbiformes, persistentes. Flores homomórficas, 5-meras, sésseis, disco nectarífero presente; cálice $0,5-1,5 \mathrm{~mm}$ compr., campanulado ou tubuloso, puberulento; corola 4-6,5 mm compr., infundibuliforme, glabra, lacínias puberulentas; androceu 22-35 estames, 13-20,5 mm compr., tubo $6,8-10,8 \mathrm{~mm}$ compr., exserto; ovário 1-2 mm compr., seríceo. Folículos 5,5-11 × 1,5-2 $\mathrm{cm}$, retos ou falcados, lineares, plano compressos, margens estreitas, puberulentos; sementes 10-14,5 $\times 8-12 \mathrm{~mm}$, plano-discoides, monocolores, testa membranácea, pleurograma ausente.

Material selecionado: Aracruz, Retiro, 6.IV.1992, fr., O.J. Pereira et al. 3383 (VIES). Cachoeiro do Itapemirim, Duas Barras, 10.X.2008, fr., J.M.L. Gomes 3191 (VIES). Colatina, Novo Brasil, 13.IX.1991, fl., V. de Souza 186 (CVRD). Conceição da Barra, Parque Estadual de Itaúnas, 29.III.2000, O.J. Pereira \& A.M. Assis 6065 (VIES). Domingos Martins, margem do Rio Jucu, 17.I.2001, fl., O.J. Pereira \& E. Espindula 
6748 (VIES). Linhares, estrada Linhares à Fazenda Maria Bonita, via Regência, 10.I.2008, fl., A.A. da Luz 500 (CVRD). Vila Velha, Parque Natural Municipal de Jacarenema, 7.II.2012, fl. e fr., D.T. Iglesias et al. 07 (VIES).

Restrita ao Brasil, onde ocorre nos estados da Bahia, Espírito Santo, Minas Gerais, Paraná, Pernambuco, Rio de Janeiro e São Paulo, em Floresta Atlântica (BFG 2015). No Espírito Santo, a variedade tem registro de ocorrência nas quatro mesorregiões, principalmente no Litoral Norte, em Mata de Encosta, Mata de Tabuleiro e Restinga. Zygia latifolia var. glabrata caracteriza-se por apresentar as folhas bipinadas com apenas 1 par de pina, com o pecíolo reduzido, 5-7 foliólulos por pina e os frutos puberulentos. Coletada com flor em janeiro, fevereiro e setembro, e com fruto em fevereiro, abril e outubro. Conhecida popularmente como ingá.

\section{Agradecimentos}

Aos curadores dos herbários que disponibilizaram a consulta ao acervo; ao herbário VIES, o uso das instalações; ao ilustrador botânico Reinaldo Pinto, a qualidade das ilustrações; ao órgão financiador Conselho Nacional de Desenvolvimento Científico e Tecnológico (CNPq), a bolsa de Mestrado concedida à primeira autora; à FAPEMIG/PPM 0092/2014 e à CAPES/ PNADB, os recursos financeiros.

\section{Referências}

Barneby RC \& Grimes JW (1996) Silk tree, guanacaste, monkey's earring. A generic system for the Synandrous Mimosaceae of the Americas. Abarema, Albizia and allies. Memories of the New York Botanical Garden 74: 1-292.

Barneby RC \& Grimes JW (1997) Silk tree, guanacaste, monkey's earring. A generic system for the synandrous Mimosoideae of the Americas. Pithecellobium, Cojoba, and Zygia. Memories of the New York Botanical Garden 74: 1-161.

Barneby RC (1998) Silk tree, guanacaste, monkey's earring. A generic system for the synandrous Mimosoideae of the Americas. Calliandra. Memories of the New York Botanical Garden 74: 1-223.

Barroso GM, Morim MP, Peixoto AL \& Ichaso CLF (1999) Frutos e sementes: morfologia aplicada à sistemática de dicotilêdoneas. UFV, Viçosa. 443p.

Bentham G (1865) Leguminosae. In: Bentham G \& Hooker JD (eds.) Genera Plantarum 1: 434-600.

BFG - The Brazil Flora Group (2015) Growing knowledge: an overview of seed plant diversity in Brazil. Rodriguésia 66: 1085-1113.
Brown GK, Murphy DJ, Miller JT \& Ladiges PY (2008) Acacia s.s. and its relationship among tropical legumes, tribe Ingeae (Leguminosae: Mimosoideae). Systematic Botany 33: 739-751.

Dutra VF, Alves-Araújo A \& Carrijo TT (2015) Angiosperm checklist of Espírito Santo: using electronic tools to improve the knowledge of an Atlantic Forest biodiversity hotspot. Rodriguésia 66: 1145-1152.

Fernandes JM (2011) Ingeae Benth. (Leguminosae, Mimosoideae) no estado de Minas Gerais, Brasil: taxonomia, morfoanatomia de nectários extraflorais e padrões de distribuição geográfica. Tese de Doutorado. Universidade Federal de Viçosa, Viçosa. 298p.

Fidalgo O \& Bononi VLR (1989) Técnicas de coleta, preservação e herborização do material botânico. Instituto de Botânica, São Paulo. 61p.

Forzza RC et al. (2010) Síntese da diversidade brasileira. In: Forzza RC et al. Catálogo de plantas e fungos do Brasil. Vol. 1. Andrea Jakobsson Estúdio, Instituto de Pesquisas Jardim Botânico do Rio de Janeiro, Rio de Janeiro. Pp. 21-42.

IBGE - Instituto Brasileiro de Geografia e Estatística (2011) Sinopse do censo demográfico 2010. IBGE, Rio de Janeiro. 261p. Disponível em <https:// biblioteca.ibge.gov.br/visualizacao/livros/liv49230. pdf $>$. Acesso em 10 setembro 2014.

IBGE - Instituto Brasileiro de Geografia e Estatística (2012) Manual técnico da vegetação brasileira: sistema fitogeográfico, inventário das formações florestais e campestres, técnicas e manejo de coleções botânicas, procedimentos para mapeamentos. IBGE, Rio de Janeiro. 275p.

Iganci JRV (2008) Abarema Pittier (Leguminosae, Mimosoideae) no Brasil extra-amazônico. Dissertação de Mestrado. Instituto de Pesquisas Jardim Botânico do Rio de Janeiro, Rio de Janeiro. 160 p.

Iganci JRV \& Morim MP (2009) Abarema (Leguminosae, Mimosideae) no estado do Rio de Janeiro, Brasil. Rodriguésia 60: 581-594.

Iganci JRV \& Morim MP (2012) Abarema (Fabaceae, Mimosideae) in the Atlantic Domain, Brazil. Botanical Journal of the Linnean Society 168: 473-486.

IJSN - Instituto Jones dos Santos Neves (2011) Espírito Santo em mapas. Vitória. 97p. Disponível em $<\mathrm{http}$ :// www.ijsn.es.gov.br/Sitio/images/flippingbook/ es_em_mapas_3a_edicao/Es_em_Mapas_3_edicao. pdf $>$. A cesso em 20 julho 2014 .

Lewis GP \& Rico Arce ML (2005) Tribe Ingeae. In: Lewis GP, Schrire B, Mackinder B \& Lock M (eds.) Legumes of the world. The Royal Botanic Gardens, Kew. Pp. 193-213.

Lewis GP, Schrire BD, Mackinder BA \& Lock JM (2005) Legumes of the world. Royal Botanic Garden, Kew. 577p. 
Luckow M, Miller JT, Murphy DJ \& Livshultz T (2003) A phylogenetic analysis of the Mimosoideae (Leguminosae) based on chloroplast DNA sequence data. In: Klitgaard BB \& Bruneau A (eds.) Advances in legume systematics. Part 10. Royal Botanic Gardens, Kew. Pp. 197-220.

Martinelli G, Valente ASM, Maurenza D, Kutschenko DC, Judice DM, Silva DS, Fernandez EP, Martins EM, Barros FSM, Sfair JC, Santos Filho LAF, Abreu MB, Moraes MA, Monteiro NP, Pietro PV, Fernandes RA, Hering RLO, Messina T \& Penedo TSA (2013) Avaliações de risco de extinção de espécies da flora brasileira. In: Martinelli G \& Moraes MA (orgs.) Livro vermelho da flora do Brasil. Instituto de Pesquisa Jardim Botânico do Rio de Janeiro, Rio de Janeiro. Pp. 60-103.

Mesquita AL (1990) Revisão taxonômica do gênero Enterolobium Mart. (Mimosoideae) para a região Neotropical. Dissertação de Mestrado. Universidade Federal Rural de Pernambuco, Recife. 219p.

Mesquita AL (1993) Enterolobium glaziovii (Benth.) Mesquita, comb. nov. et "status novum" para as regiões Sudeste e Nordeste do Brasil. Acta Botânica Brasilica 7: 17-23.

Nielsen I (1981) Ingeae. In: Polhill RM \& Raven PH (eds.) Advances in legume systematics 1. Royal Botanic Gardens, Kew. Pp. 173-190.

Pennington TD (1997) The genus Inga: botany. Royal Botanic Gardens, Kew. 844p.

Polhill RM (1994) Classification of the Leguminosae. In: Bisby FA, Buckingham J \& Harbone JB (eds.) Phytochemistry dictionary of the Leguminosae. Chapman and Hall, New York. Pp. 45-54.

Queiroz LP, Cardoso DBOS, Conceição A S, Souza ER,
Tozzi AMGA, Pérez APF, Silva MJ, Simon MF, Mansano VF, Costa JAS, Rodrigues WA, Lima LCP \& Bocage A (2009) Leguminosae. In: Giulietti AM, Rapini A, Andrade MJG, Queiroz LP, Silva JMC (org.) Plantas raras do Brasil. Conservação Internacional, Belo Horizonte. Pp. 212-236.

Radford AE, Dickison WC, Massey JR \& Bell CR (1974) Vascular plant systematics. Harper \& Row, New York. 891p.

Souza ER \& Queiroz LP (2004) Duas novas espécies de Calliandra Benth. (Leguminosae - Mimosoideae) da Chapada Diamantina, Bahia, Brasil. Revista Brasileira de Botânica 27: 615-619.

Souza ER, Lewis GP, Forest F, Schnadelbach AS, van den Berg C \& Queiroz LP (2013) Phylogeny of Calliandra (Leguminosae: Mimosoideae) based on nuclear and plastid molecular markers. Taxon 62: 1200-1219.

Thiers B [continuamente atualizado] Index Herbariorum: a global directory of public herbaria and associated staff. New York Botanical Garden's Virtual Herbarium. Disponível em $<$ http://sweetgum.nybg. org/ih/> . Acesso em 23 março 2017.

Thomaz LD (2010) A Mata Atlântica no estado do Espírito Santo, Brasil: de Vasco Fernandes Coutinho ao século 21. Boletim do Museu de Biologia Mello Leitão (Nova Série) 27: 5-20.

Wojciechowski MF, Lavin M \& Sanderson MJ (2004) A phylogeny of legumes (Leguminosae) based on analysis of the plastid matK gene resolves many well-supported subclades within the family. American Journal of Botany 91: 1846-1862.

Wu D \& Nielsen IC (2010) Tribe Ingeae. In: Wu ZY, Raven PH \& Hong DY (eds.) Flora of China 10: 60-71.

Lista de exsicatas adicionais examinadas

AA Luz 235 (1.3). AG Oliveira 508 (1.4). AP Fontana 1528 (3.2). BC Silva 198 (7.1). DA Folli 922, 5549 (1.1), 1324 (2.1), 6544 (4.1), 2885, 5536, 5548, 5720 (7.1). DR Couto 815 (7.1). G Hatschbach 69183 (1.4). GL Farias 146 (2.1), 46 (5.1). G Martinelli 9723 (1.4). GS Siqueira 623 (1.1), 412 (1.3), 658 (1.4), 633 (1.5). HC Lima 6649 (1.4). IA Silva 245 (7.1). J Iganci 261 (1.5). JML Gomes 3561, 3578, 3612, 3628 (2.2). J Spada 6/77 (1.3), 59 (2.1), 107/72 (5.1). OJ Pereira 801, 4622, 5502, 5267 (1.1), 2821, 2850 , 3033, 3465, 3779, 4117, 4132, 4271, 4417, 5712 (1.4), 3242, 3819 (2.1), 3707, 4994, 7115 (2.2), 3367, 3433 (7.1). LD Thomaz 7434 (1.2). LFS Magnago 1091 (2.2). MC Souza 341 (1.4). M Ribeiro 07 (1.4). RD Ribeiro 765 (1.4). RR Vervloet 309 (1.2). V Demuner 1899, 2247 (2.2). V Souza de 271 (5.1). Weiler Junior 25 (1.1). 
